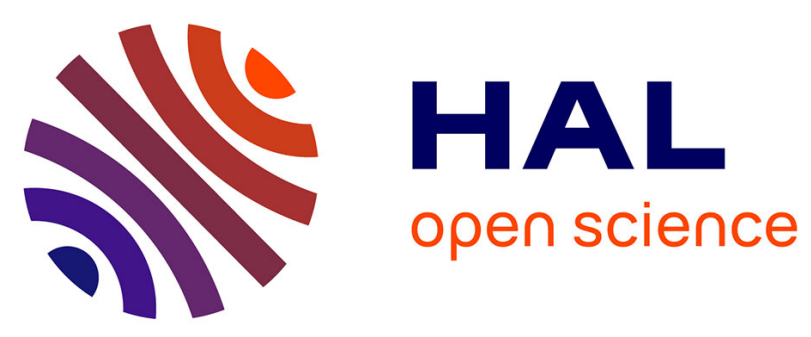

\title{
Developing as Consumers
}

Valérie-Inès de La Ville, Valérie Tartas

\section{To cite this version:}

Valérie-Inès de La Ville, Valérie Tartas. Developing as Consumers. David Marshall. Understanding Children as Consumers, Part one: Children as consumers, Sage, pp.23-40, 2010, SAGE Advanced Marketing Series, 10.4135/9781446251539.n2 . hal-01627970

\section{HAL Id: hal-01627970 https://hal.science/hal-01627970}

Submitted on 26 Oct 2018

HAL is a multi-disciplinary open access archive for the deposit and dissemination of scientific research documents, whether they are published or not. The documents may come from teaching and research institutions in France or abroad, or from public or private research centers.
L'archive ouverte pluridisciplinaire HAL, est destinée au dépôt et à la diffusion de documents scientifiques de niveau recherche, publiés ou non, émanant des établissements d'enseignement et de recherche français ou étrangers, des laboratoires publics ou privés. 


\section{Developing as Consumers}

by

Valérie-Inés de La VILLE

Professor in Business Policy and Marketing - Head of The European Centre for Children's Products Business Administration Department - University of Poitiers - France

AND

\section{Valérie TARTAS}

Lecturer and researcher in Developmental Psychology - Cognition, Communication and Development Laboratory - University of Toulouse 2 - France

\section{Chapter Aims}

- To introduce three perspectives used by marketing researchers and practitioners to explain how children develop as consumers :

- a classic developmental-stage based perspective which focuses on the progressive acquisition of economic knowledge by children

- a widespread process-centered model which aims at explaining how children interact with socialization agents to acquire economic abilities

- a more recent framework drawing on cultural psychological theory that suggests that children are immersed in the realm of mass consumption culture

- To discuss the cornerstone elements of these three models and the contrasting explanations they propose about the learning processes through which children develop as consumers

- To delineate new research avenues in order to account for the creative capacities of children when they participate in joint consumption activities

\section{Introduction}

Scientific articles aimed at linking the realms of childhood and economy appeared in the early 1950's and dealt mainly with the role children play when they take part in family consumption practices (Strauss, 1952). Thus consumer socialisation is a relatively recent research area as the concept itself was defined in 1974 for the first time by S. Ward: "The processes by which young people acquire skills, knowledge, and attitudes relevant to their functioning as consumers in the marketplace" (Ward 1974: 2). This broad definition calls for an interdisciplinary perspective, including social and cultural backgrounds, language skills, psychological development, emotional and symbolic dimensions, etc. (Robertson and Feldman 1976). Thus, this chapter aims to clarify the contributions of three established perspectives to the understanding of the development of children's abilities to behave as consumers. Moreover, in the process of growing up, children are involved in social relationships that go far beyond their direct or indirect participation in mere buying behaviours (Oestergaard and Jantzen, 2000). This means that through consumption activities, children learn a lot about contemporary society and the diverse social rules that prevail according to different social situations... 
I - Developing as Consumers... by climbing a succession of cognitive stages in the use of economic notions

A first batch of marketing research draws on the seminal work by the Swiss psychologist Jean Piaget (1948) and applies it to the analysis of the development of economic thinking by children. This research perspective has been driven by the question of "what" does the child know, the kind of economic knowledge the child is able to use when he or she is confronted with practical problems linked to consumption activities. Following Piagetian terms, development is regarded as the adaptation to the outside world, i.e. the construction by the individual of increasingly elaborated cognitive mechanisms to improve his or her control over the surrounding world. This developmental process unfolds in a natural way: by individually acting on external objects, the child gradually builds up skills related to his environment that will in turn impose its own structures on him or her. Thus, growing and learning imply passing through various stages of development which enable the child to control concrete logical operations, and later on, formal logical operations during adolescence. Development gives access to the increasingly complex logical designs that characterise adult thought which is regarded as the ultimate aim of child developmental processes.

\subsection{A three-stage cognitive model of consumer development}

The American researcher Deborah Roedder-John (1999) has documented 25 years of accumulated international research on children in relation to their role as consumers. She incorporated the findings into a general conceptual framework that conceives consumer socialisation as progressing through a series of three sequential stages capturing major cognitive shifts from preschool to adolescence: the perceptual stage ( 3 to 7 years), the analytical stage ( 7 to 11 years) and the learned stage (11 to 16 years) (see Table 1). These stages, essentially defined in terms of age groups, include various dimensions that characterise children's knowledge, such as cognitive and social skills, and motives during childhood and adolescence, and are also related to children's growing sophistication with regard to products, brands, advertising campaigns, shopping, pricing, decision-making strategies, and influential strategies.

Using Piaget's theory, Roedder-John's framework seeks to identify the main shifts in children's understanding of basic economic concepts. It depicts young children's skills as being limited and only based on the perceptual skills which are not enough to understand implicit messages in advertising for example. Thus from 3 to 7 years old, children show an egocentric orientation, as they are not able to differentiate points of view, for example the persuasive perspective held by the advertiser and the need for information felt by the consumer. Moreover children's ability to deal with information is limited and prevents them from making decisions based on a plurality of dimensions, as adults do. When they gradually enter the analytical stage, this model provides descriptive information about the stages children go through, starting from fragmentary and imprecise ideas to a more logical understanding. In the analytical stage, children are becoming aware of the complexity of the market because their way of reasoning becomes more abstract and is no longer only driven by their own perceptions. The reflective stage allows pre-adolescents and adolescents to develop a critical thinking about the marketplace and how it functions. 
Table 1: Stages in Children's Development as Consumers

\begin{tabular}{|c|c|c|c|}
\hline Characteristics & $\begin{array}{c}\text { Perceptual stage } \\
\text { 3-7 years } \\
\end{array}$ & $\begin{array}{c}\text { Analytical stage } \\
7-11 \text { years }\end{array}$ & $\begin{array}{c}\text { Reflective stage } \\
11-16 \text { years } \\
\end{array}$ \\
\hline \multicolumn{4}{|c|}{ Knowledge structures } \\
\hline Orientation & Concrete & Abstract & Abstract \\
\hline Focus & Perceptual features & $\begin{array}{c}\text { Functional/underlying } \\
\text { features }\end{array}$ & $\begin{array}{c}\text { Functional/underlying } \\
\text { features }\end{array}$ \\
\hline \multirow[t]{2}{*}{ Complexity } & Unidimensional & $\begin{array}{c}\text { Two or more } \\
\text { dimensions } \\
\end{array}$ & Multidimensional \\
\hline & Simple & Contingent (if-then) & Contingent (if-then) \\
\hline Perspective & $\begin{array}{c}\text { Egocentric } \\
\text { (own perspective) }\end{array}$ & $\begin{array}{c}\text { Dual perspectives } \\
\text { (own+ others) }\end{array}$ & $\begin{array}{l}\text { Dual perspectives in } \\
\text { social context }\end{array}$ \\
\hline \multicolumn{4}{|c|}{ Decision-making and influence strategies } \\
\hline Orientation & Expedient & Thoughtful & Strategic \\
\hline \multirow[t]{2}{*}{ Focus } & Perceptual features & $\begin{array}{c}\text { Functional/underlying } \\
\text { features }\end{array}$ & $\begin{array}{c}\text { Functional/underlying } \\
\text { features }\end{array}$ \\
\hline & Salient features & Relevant features & Relevant features \\
\hline \multirow[t]{2}{*}{ Complexity } & Single attribute & Two or more attributes & Multiple attributes \\
\hline & $\begin{array}{l}\text { Limited repertoire of } \\
\text { strategies }\end{array}$ & $\begin{array}{c}\text { Expanded repertoire of } \\
\text { strategies }\end{array}$ & $\begin{array}{c}\text { Complete repertoire of } \\
\text { strategies }\end{array}$ \\
\hline Adaptive & Emerging & Moderate & Fully developed \\
\hline Perspective & Egocentric & Dual perspectives & $\begin{array}{l}\text { Dual perspectives in } \\
\text { social context }\end{array}$ \\
\hline
\end{tabular}

(source: Roedder-John D., 2002: 32)

Based on this stage-oriented framework of child development, Roedder-John presented five areas of research that she considers are the effects of the process of consumer socialisation, as they imply an acquisition of various knowledge, skills and values, i.e. advertising and persuasion knowledge, transaction knowledge, and decision-making skills and abilities, negotiation skills, values and motives of consumption.

\subsection{Limits of this framework through a selection of three key critical comments}

As a managerial transposition of the cognitive developmental theory of Piaget, this framework of consumer socialisation was mainly addressed to marketing managers with a two-fold aim: firstly, to describe the development of consumer socialisation through three cognitive stages and secondly, to offer a 'toolkit' to help marketing practitioners improve their targeting of children and adolescents. Roedder-John acknowledged that she focused on research only seen from a managerial and marketing perspective, and that she examined selected consumer research published in marketing and communication journals, which lead her to exclude other research areas dealing with child development. This might explain why her theoretical framework overlooked three important points:

- Cognitive development is driven by biological or internal factors: To go beyond mere physical objects that were the main focus in Piagetian's studies, she used Selman's theory (1980) which integrates the social dimensions of child development and documents the changes in children's way of thinking about the social world... Although it takes into account children's capacity to consider anothers' point of view and to behave in accordance with a conventional system of social roles, this 
perspective ends in a very limited understanding of child consumer socialisation as it conceives socialisation itself as a fundamentally solitary cognitive construction by an individual. From a Piagetian perspective, the socialisation process of the child is seen only from the point of view of the endogenous factors that lead the child to pass from self-centredness to other-centeredness. In such a perspective, only internal processes may explain the development of economic thinking and the transitions between the different stages.

- The use of age as a marker of cognitive skills: by placing 'age' - instead of the internal structure of thought - as the cornerstone of her framework, Roedder-John diverted Piagetian theory from its own foundations. She conceived development only as a difference of degree in the understanding and use of economic knowledge, and not as a qualitative difference in the nature of reasoning involved in economic activities and market situations. Whereas, in Piagetian terms, the idea of stages is much more complex and relates to the internal cognitive mechanisms of assimilation, accommodation and equilibration. Jean Piaget himself stressed that what should be retained from his model is the succession of stages and not the age ranges because they could vary greatly according to cultural and social contexts (Bringuier 1977: 57). However, some researchers do criticise stage-oriented theories of child development as, in the context of a globalising marketplace fostering the internationalisation of mass media and consumer culture, the everyday life of contemporary children is extremely different from that of former times (Gunter a,d Furnham, 1998).

- The exclusive focus on logical reasoning: by considering children as 'economic problem solvers' trying to succeed in an adult economic world (Duveen, 1994), managerial approaches promote a specific kind of knowledge and reasoning - logical - while overlooking a major mode of human thought, the narrative one. As Bruner (1990) pointed out, two major modes of thinking characterise human cognition: the 'syntagmatic' or 'narrative' mode and the 'paradigmatic' or 'logical' mode. In the first, events are connected to one another through a narrative frame allowing the creation of stories, whereas in a paradigmatic mode, reasoning faculties pursue logical truth. If the child develops his or her narrative capacity very early in everyday mundane contexts, the paradigmatic thought - or logic-scientific - only emerges after systematic education, for which the institutional dimension has received little consideration within the Piagetian theory (Cram and Ng, 1999: 300).

In short, we can conclude that the theory of cognitive development has played a dominant role in management academic circles as well as in marketing practice (Siegel and al., 2002). Nevertheless, critics have pointed out that socialisation should be defined as a function of environmental influences applied to the person rather than as a purely individual cognitive process.

II - Developing as Consumers... by acquiring social skills and knowledge through interaction with socialisation agents

A second course of study endeavours to overcome certain limitations of the cognitive-driven approaches by incorporating the social aspects of economic development, using various social variables and the social education model elaborated by Bandura (1977). This process-oriented approach to consumer socialisation has gained ground in order to find out "how" the child acquires his or her economic knowledge.

\section{1 - Child economic socialisation as a synthesis at the crossroads of three fields}


Moschis and his colleagues (Moschis and Churchill 1978; Moschis and Moore 1979) developed an alternative theory of child consumer socialisation that offered a more accurate definition of consumer socialisation. From this perspective, Lassare and Roland-Lévy's conceptual framework aims at linking four variables that derive from general socialisation theories: 1) the socialisation agents (peers, family, school, mass media); 2) the learning process (in particular imitation or vicarious learning); 3 ) the social structure variables (age, sex, social class); 4) the learning content (Lassare and Roland-Lévy, 1989). It represented a clear invitation to explore how the socialisation process actually works in everyday and casual social activities as well as in more formal social contexts.

Figure 2: Consumer Socialisation Process

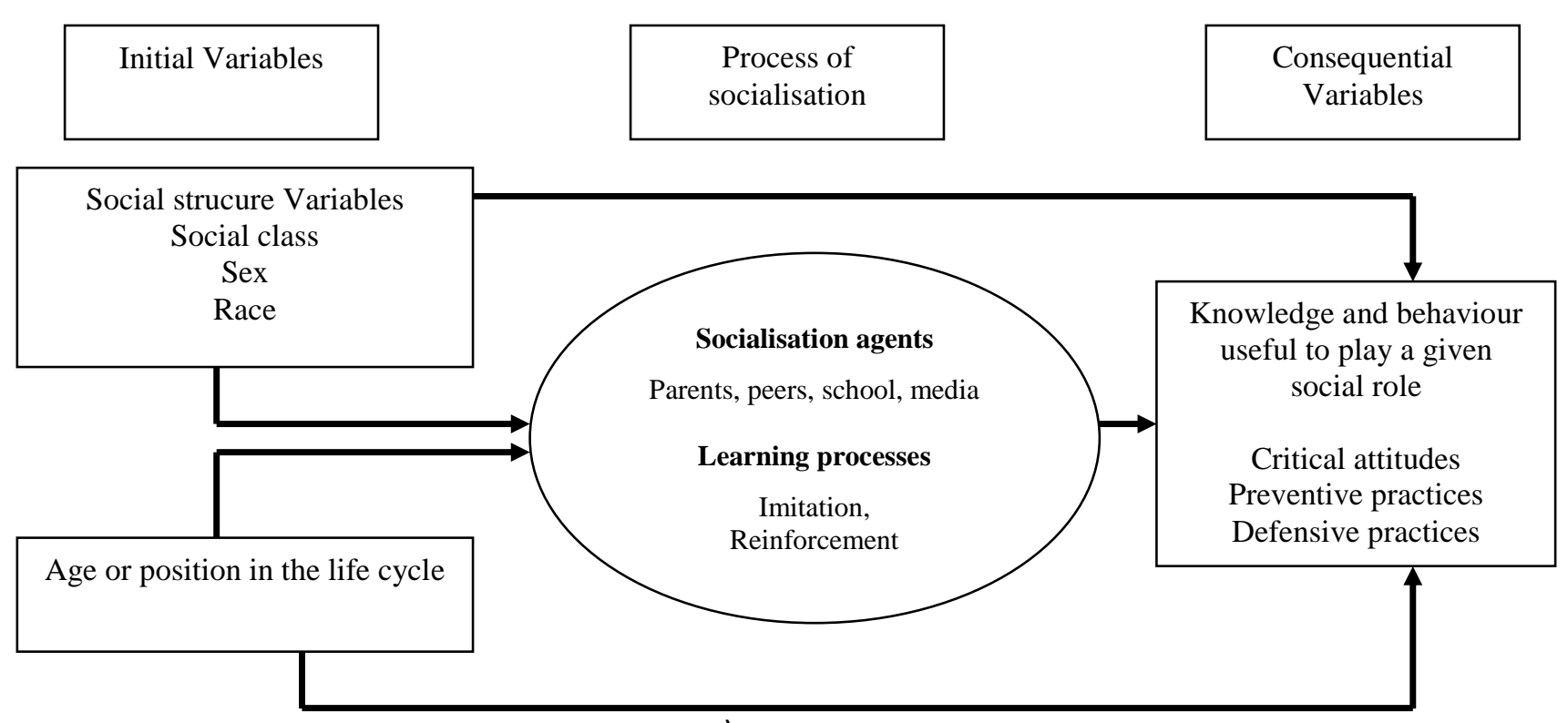

(source: adapted from Moschis and Churchill, 1978)

This theoretical framework is an attempt to produce a consistent synthesis of three different perspectives. These three domains were considered inter-related, their combination allowing a broader understanding of economic socialisation processes.

First of all, the Piagetian theory revisited by Berti and Bombi (1989) which identified that children are active role-takers in the economic domain. Drawing on these studies, the authors defined economic socialisation as an on-going process by which the child assimilates knowledge and reasoning about the economic world and consumption practices. The emphasis was put on children's methods of interpreting the marketplace as well as on the specificity of the cognitive operations needed to understand economic notions.

Secondly, the social role model theory, which suggests that a child is supposed to learn how to play different roles in society, such as pupil, sibling, grandson, as well as... consumer. As far as the latter is concerned, the economic education is achieved in practice owing to four main sources of information: parents and family habits, peers, advertising and the products themselves. The inclusion of social roles emphasised the importance of social environment on children's cognitive elaborations. It considered the influences of parents and peers as well as the effect of gender as the main factors that help children become active economic agents - able to choose a product, to learn how to buy it and to understand how the marketplace is governed. 
Finally, Bandura's (1977) theory of social learning which suggests that two central processes observation and imitation (mimicry of other consumers: parents, peers, brothers and sisters, etc.) - can explain both real consumer behaviour (such as comparing prices and products) and more complex and abstract notions (such as purchasing power and taxes). The role of social environment is explained through two main independent variables: on the one hand, the social environment in which the child is involved, and on the other, the nature of the reinforcement or feed-back provided by the environment.

The main contribution of this perspective is to have linked cognition to social interactions and to have exceeded the limitations of a strictly individualistic cognitive developmental approach. The authors focused on the way the child is integrated into society by the appropriation of the roles enacted by environmental models in family circles, peer groups and through mass media.

\subsection{Limits of this framework through a selection of three key critical comments}

Process-oriented theoretical frameworks about child economic socialisation perceive social environment through two key variables: the child's social environment and the feed-back and product reinforcement provoked by this same environment. Thus, this process approach tries to consider the individual and the cognitive operations involved in economic situations as well as the social contexts in which the child develops. However, in spite of its ambitious attempt, this framework leaves three important questions unanswered.

- A limited scope of exploration that ignores young children: this theoretical perspective allowed a recombination of several research results obtained through different methodologies: surveys through semi-structured interviews, face-to-face interviews in focus groups, observations and questionnaires. Nevertheless, the first shortcoming comes from the empirical studies that are mainly focused on pre-adolescents, adolescents, young adults and adults, neglecting young children such as preschool and early school children (Lachance and Legault, 2007). As a result, this process perspective only covers a limited explanatory scope as it favours pre-adolescents and adolescents.

- Vicarious learning cannot account for children's creative capacities: the 'modelling exposure' perspective considers that the fact of being confronted by parental economic behaviour is sufficient to trigger the development of the child's economic skills. But then a crucial question remains unanswered: how can we explain the emergence of new behaviours in children, adolescents, or adults? Observation and imitation impede the explanation for the emergence of creative behaviour which does not just come from behaviours already developed within family circles or peer groups. In psychology, the modelling approach has been criticised: imitation of adults or more experienced children is neither a necessary nor a sufficient condition to explain children's cognitive progressions (Doise and Mugny, 1981).

- Interaction does not constitute the key unit of analysis: although the process models highlight the role of others - individuals enacting their institutional roles - as a central explanatory factor, from a methodological standpoint, social interactions themselves do not appear as being the central focus of empirical analysis. In fact the individual and social issues are seen as two separate entities which certainly need to be re-entangled, but in the end, the individual remains the cornerstone of the analysis and the theoretical elaboration. Social influence approaches maintain a focus on the individual as the basic unit of analysis and examine the influence of 'outside' social forces. In the social influence perspective, since individual competence is traditionally seen as separate from environmental circumstances, individuals are considered to possess knowledge prior to being involved in a social interaction, then to have a social experience allowing consideration of other 
possible courses of action, and finally to absorb them so they become a part of their personal repertoire.

As Cram and Ng (1999) noted, "both psychological and marketing approaches (social learning theory) have inherent faults in terms of their ability to provide a full picture of children's consumer socialisation. These faults include a lack of understanding of children as active agents within a cultural context which, in turn, has resulted in a dearth of cross-cultural research and the widespread acceptance of the white, middle-class nuclear family as the "normal" context within which children are socialised". They develop an approach called 'scaffolding' based on Bruner and Haste's (1987: 1) definition of socialisation as a process through which children acquire a "framework for interpreting experience and learning how to negotiate meaning in a manner congruent with the requirements of culture". Their 'scaffolding' approach ties three consumption-related concepts - 'ownership', 'money' as a medium of exchange, and 'price' - which provide children with a framework for integrating an increasing variety of consumption experiences. The authors discussed how these concepts validate and support children's consumer socialisation, leading to a wider perspective of consumer socialisation.

III - Developing as Consumers... by transforming children's participation in joint consumption activities

A more recent approach draws on cultural psychological theory and considers that children are immersed in the realm of mass consumption culture. From a theoretical standpoint, the emphasis is on examining how children actually participate in socio-cultural activities and especially how they take part in consumption activities. To understand how children learn and develop through participation in sociocultural activities, it is necessary to grant that cultural meaning is more than the mere addition of changes in individual thinking that result from social interaction and discussion with other participants (Rogoff 1998: 686). In this perspective, developmental transitions are approached through the transformation of children's roles in various socio-cultural activities related to consumption.

\subsection{Consumption as a mediated and mediating joint activity}

Within this framework, the child is clearly integrated into a social body with which he or she interacts and from which he or she receives help and reassurance to dare participate in mundane social life. Consequently, the relevant unit of analysis is certainly not the isolated child confronted with a problem to be dealt with, but rather the joint activity developed within an interaction 'child - adult', or 'child more experienced child' or a 'small group' confronted with a practical problem - purchase decision, defining a socially acceptable use of the object... By engaging in a joint activity with a more experienced partner, the child discovers the cultural meaning of objects.

Vygotsky used the concept of 'psychological' or 'semiotic' tool to account for the relationship between the individual and the external world (Wertsch 1985; Rogoff 1998). Child consumption constitutes a social activity mediated by various cultural tools such as the language, the social standards called upon, the rhetoric invoked, and the purchased objects or products themselves. Through mundane activities, the child gradually integrates a conventional language peculiar to consumption - such as concepts of brands, prices, quality, comparisons between products - and a set of social standards relating to consumption in a given cultural context - such as mastered references, search for identity, membership within a group, and feeling of belonging to a social class (Gronow and Warde, 2001). Thus, studying the psychological tools or the systems of signs used by the child during his or her development as an economic actor, enables a precise analysis of how children understand and practice consumption. To obtain what he or she wishes, the child must tell an appropriate story and know how to present its 
actions and objectives in order to make them legitimate within specific social groups: family circles or peer groups. As the narrative capacities of the child increase in the process of economic socialisation, researchers can analyze the evolution of children's accounts of their consumption practices. Towards 3 to 4 years, children can be regarded as 'experts' in the use of various narrative forms, knowing how to handle different rhetorical registers to evoke empathy in their close relations, which explains how children influence family purchases.

This leads us to consider that children develop as economic actors within a complex cultural system that combines several interdependent dimensions (see Figure 3). In the joint consumption activity, three elements are interwoven:

- The child is never alone but is always guided by others - adult caregivers and more experienced children - to question the practices of consumption and to construct socially shared meanings.

- The term 'cultural object' covers any socially and historically created product (not only the material and physical characteristics of the object but also its symbolic and semiotic dimension).

- The cultural object on which attention is focused is a socially and historically created product that includes in its design a technical, social and commercial background. This institutional background strongly directs its potential uses.

Figure 3: Consumer socialisation as a mediating and mediated cultural experience

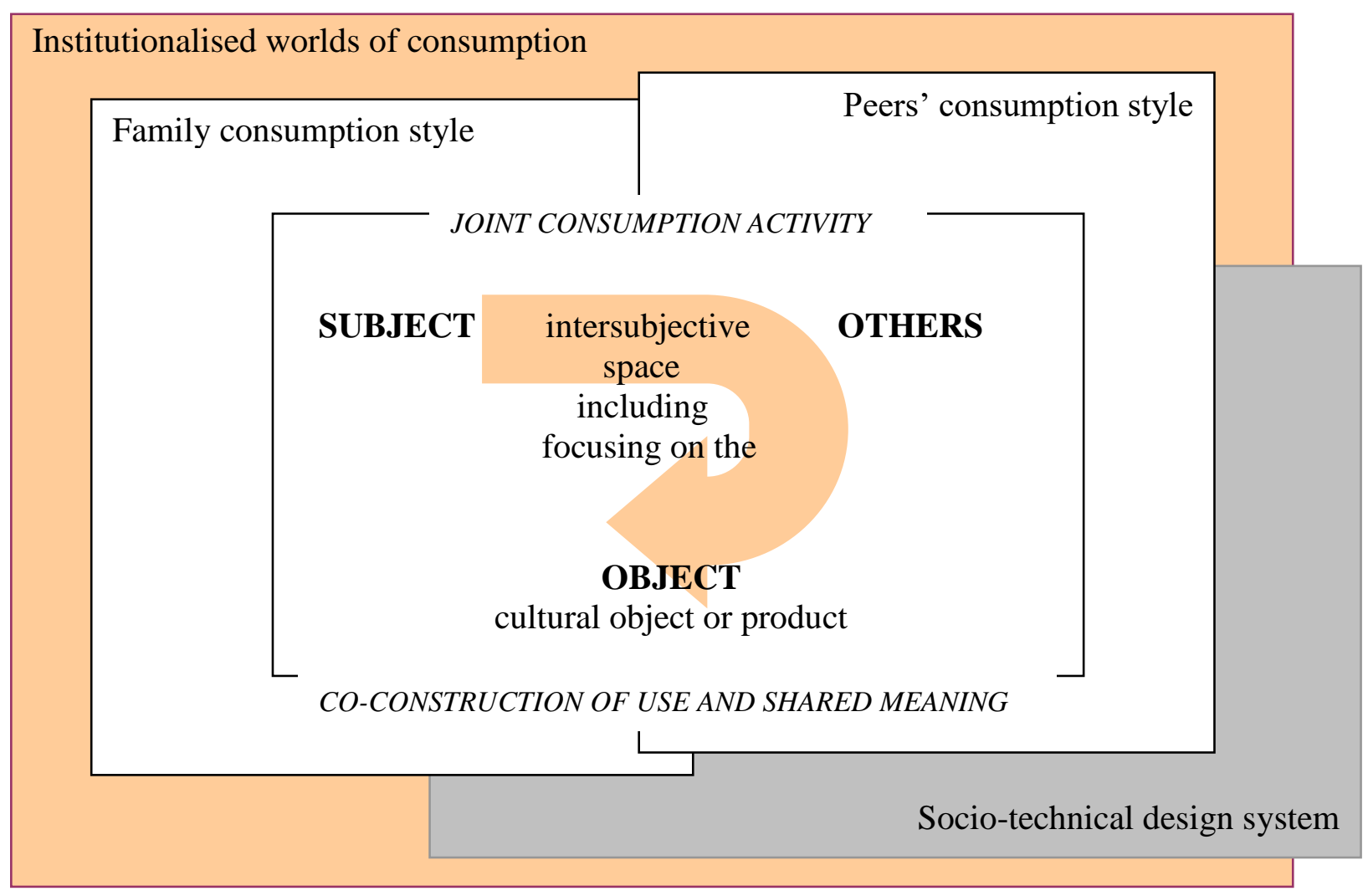

(source: De La Ville \& Tartas, 2006)

The meaning of children's consumption is framed both by the normative demands of the family's consumption style and the normative requirements of peers' consumption styles. The child has to learn to deal with the conflictive requirements held by the different social groups to which he or she belongs (Page and Ridgway, 2001). Moreover, beyond these face-to-face relationships, children's consumption practices are also enabled and constrained by wider institutional systems including: 
- the institutionalised consumption arenas (i.e. distribution and retailing, regulatory requirements, socially admitted sales techniques, sales on Internet, cultural events like Christmas, Easter, Carnival festivities, etc.), and

- the ongoing innovativeness of the socio-technical system that bring new possibilities to design products for children. For example "smart toys" or interactive cuddly toys mix electronics and traditional techniques and reflect the development of the toy industry especially in relation to technological innovation.

Within this system, some mediators developed by managers play a major role such as:

- Packaging: structures and channels children's learning experiences by constraining the categorisation process used to recognize, classify and compare products (Cochoy, 2002)

- Brand characters: creates an affective relationship between the brand and the child and establishes brand recognition by young consumers (Lawrence, 2003)

- Advertising: the mass media (Kline, 1993 and 2003 ; Tufte 2003) contribute to the diffusion of values, social norms, symbolic languages and behaviours linked to consumption practices.

As a consequence, children's consumption practices cannot be reduced to a mere purchase decision: educational, social and institutional dimensions are at the core of the long process allowing children to take part in consumption realms. Moreover, when using an item, the child discovers and learns important information about social life and its normative requirements. Thus, child consumption is both a mediated and a mediating social activity through which the child learns many things far beyond consumption itself (La Ville and Tartas, 2005). When choosing a gift for a birthday party, the child learns that different social rules have to be called on if the beneficiary is a boy, a girl, or an adult, etc. (Cook, 2002).

\subsection{Learning to consume: moving from peripheral to central participation}

Considering this complex system, the central focus of inquiry becomes: how do children participate in socio-cultural consumption activities and how does their position change from being peripheral participants (Lave and Wenger, 1991) - as users of a product bought by their parents, as observers of buying situations...-, to central participants - as decision-makers on some categories of food products, as recognized experts of some specific products? Indeed, learning to consume is not simply a matter of socialisation: it supposes the child is able to adjust his level of participation in the activity depending on varied socio-cultural rules (Rogoff and al., 2006) In this perspective, research should focus on deciphering the variety of consumption activities in which children are involved and on understanding the social and cultural conditions that allow them to adjust their participation to different degrees:

$1^{\circ}$ ) a peripheral participation - where the young children are mainly in a position of observers - when discovering the items bought back home by their parents or older siblings or when accompanying their parents to shop in traditional markets, retail outlets or when shopping on-line at home ;

$2^{\circ}$ ) a more focused and active participation of children through direct and indirect prescription concerning the items about which their caregivers, peers or siblings consider, value, and legitimate their desire and point of view;

$3^{\circ}$ ) a central participation, where children act as active and competent consumers, able to legitimately decide how to spend their own pocket money in some consumption areas that are culturally defined as specific spaces of childhood within a cultural community.

This cultural perspective highlights that children are able to create their own social rules and to modify words and objects belonging to adulthood. In doing so, they generate their own socially shared meanings and cultures. The heroes and celebrities they admire, the new forms of narratives they explore, the games and playing activities they are involved in, the possibilities brought by the technologies they use, etc. are constitutive elements of children's culture that differs from their parents' 
one (Buckingham, 2000). Birthday celebrations are a very emblematic form of children's socialisation where the convenient social rules to be followed are not defined only by parents but by children themselves (Sirota, 1999 ; Cook et al., 2002).

\section{Future Research Directions}

We have contrasted and clarified the potential contributions of three perspectives of developmental psychology to the understanding of how children gradually enter the realm of consumption practice and learn to take part in varied consumption activities. Considering socialisation itself as a fundamentally solitary cognitive construction by an individual developing through a succession of stages, researchers in management and marketing tend to perpetuate a quite restricted understanding of consumer socialisation of the child, privileging the logico-mathematical dimension of thought and overlooking the socio-cultural and historical dimensions constitutive of consumption. Thus, there still exist gaps in our understanding of the various factors that are inter-related in the process of consumer socialisation: "Cultural changes, such as the growth of single-parent families, and technological change, such as the internet, suggest the need to revisit existing findings about socialization and address new concerns." (Roedder-John, 2002: 79).

In order to enhance a comprehensive perspective on how children elaborate their reasoning about consumption activities, marketing research should focus on the syntagmatic language children practise in their daily life. The consumption activities in which children are involved constitute a 'permanent recreation', an ongoing invention through which children renew cultural assets - such as products, toys, etc. for instance - by transforming them, adapting them to particular circumstances, recombining them according to the perceived stakes, and inventing meanings that remain temporary, depending on technological and media advances, in particular through websites dedicated to information and commerce. Thus, from a methodological standpoint, this inventive dimension of child consumption practices should lead to not considering the child as a mere respondent, but as a co-researcher who actively participates in the interpretation of his own experiences as an apprentice consumer (Woodhead and Faulkner, 2003 ; Greene and Hogan, 2005).

A second line of investigation clearly includes the issue of risks linked to consumption, as well as the question of how the child's desires are considered in the daily activities in which he or she participates. As a consequence, another key research perspective could be aimed at understanding the modes of informal education - within retail stores, at home, among siblings or in peer groups - that contribute to shaping children's knowledge about consumption practices in relation to specific cultural contexts. It should lead to a reflection on the status of the child in the consumption society and the methods of setting up education for consumption aimed at increasing the degree of vigilance and reflexivity of the young consumer, and also contribute to specifying the consumption situations in which the child may be considered a vulnerable consumer in need of protection.

A third line of improvement includes the analysis of the historical, institutional and cultural aspects of joint-problem solving activities that are observed in consumption practices. In socio-cultural approaches, and pay special attention to how participants and institutions both determine the goals, means, situation, and definition of consumption activities. A reflection about theevolution of the institutional elements that enable and justify the child's position right at the heart of commercial situations is essential as it underlines that children's economic socialisation takes place within a broader historical trend in Western cultures appeared since the beginning of the XX ${ }^{\text {th }}$ century in the USA - the 'empowerment' of the child as a consumer in his own right - that provides young consumers with 
institutional, cultural, and ideological resources to legitimate their active participation in the marketplace (Cook, 2004).

\section{Discussion Questions}

- To introduce three perspectives used in marketing research to explain how children develop as consumers :

- dichotomy opposing the 'competent child' to the 'vulnerable child'

\section{References}

Bandura, A. (1977). Social learning theory. Englewood Cliffs, N.J., Prentice Hall.

Berti A. \& Bombi, A.S (1988). The child's construction of economics. Cambridge : Cambridge University Press.

Bringuier, J.C. (1977). Conversations libres avec Jean Piaget. Paris: Laffont.

Bruner, J. (1986/2000) Actual Minds, possible worlds. (trad. Française: Culture et mode de pensée: l'esprit humain dans ses œuvres). Harvard, Harvard University Press.

Bruner, J.S. (1990). Acts of meaning, Cambridge. MA: Harvard University Press

Bruner, J.S. \& Haste, H. (1987). Introduction, in J.S. Bruner \& H. Haste (Eds.), Making sense: the child's construction of the world. London: Methuen, 1-25.

Buckingham D. (2000). After the Death of Childhood. London: Polity Press,

Carlson, L., Walsh, A. Laczniak, R.N. \& Grossbart, S. (1994). Family communication patterns and marketplace motivations, attitudes and behaviours of children and mothers. The Journal of Consumer Affairs, 28, 25-53.

Cochoy, F. (2002). Une sociologie du packaging ou l'âne de buridan face au marché. Paris: Presses Universitaires de France.

Cook, D.T. (Ed.) (2002). Symbolic Childhood. New York: Peter Lang.

Cook, D.T. (2004). The commodification of childhood - The children's clothing industry and the rise of the child consumer, London : Duke University Press.

Cook, D. (2008).

Cram, F. \& Ng, S.H. (1999). Consumer Socialization, Applied Psychology: An international review, 48 (3), 297-312.

Cross, G. (2002). Valves of Desire: A Historian's Perspective on Parents, Children, and Marketing, Journal of Consumer Research, Vol.29, December, 441-447.

De La Ville, V.I. (2007). The consequences and contradictions of child and teen consumption in contemporary practice, Society and Business Review, 2 (1), 7-14.

De La Ville, V.I. \& Tartas, V. (2005). L'activité de consommation enfantine et ses médiateurs, pp. 73-88, in De La Ville V.I. (Ed.), L'enfant consommateur - Variations interdisciplinaires sur l'enfant et le marché, (The Child Consumer - Interdisciplinary variations on the child and the market) Paris: Editions Vuibert.

Deleau M. (Ed.). (1999). Psychologie du développement, Paris : Bréal. 
Doise, W. and Mugny, (1981). Le développement social de l'intelligence. Paris: Interéditions.

Duveen, G. (1994). Review of Sonuga-Burke E.J. \& Webley P. (1993) Chidlren's savings: a study of development of economic behaviour. Hove, UK: Lawrence Erlbaum Associates, Journal of Economic Psychology, 15, 375-378.

Greene, S. \& Hogan, D. (eds.) (2005). Researching Children Experience - Methods and Approaches, London: Sage.

Gronow, J. \& Warde, A. (2001). Ordinary Consumption. London: Routledge.

Gunter, B. \& Furnham, A. (1998). Children as Consumers. London and New York: Routledge

James, A., Jenks, C. \& Prout, A. (1998). Theorizing childhood. Cambridge: Polity Press

Lachance, M. \& Legault, F. (2007). College student's competence: identifying the socialization sources, Journal of Research for Consumers, 13,

Lassare, D. \& Roland Lévy, C. (1989). Understanding children's economic socialization, in Grünert K.G. \& Olander F. (Eds.). Understanding economic behaviour, Dordrecht (NL): Kluwer Academic Publishers, 347368.

Lave, J. \& Wenger, E. (1991). Situated Learning, Legitimate Peripheral Participation, Cambridge, MA: Cambridge University Press.

Lawrence, D. (2003). The role of characters in kids marketing, Journal of Adverstising and Marketing to Children, Vol. 4 (3), 43-48.

Martens, L. (2005). Learning to consume - consuming to learn: children at the interface between consumption and education, British Journal of Sociology of Education, 26 (3), 343-357.

Mick, D.G. (2007). The End(s) of Marketing and the Neglect of Moral Responsibility by the American Marketing Association, Journal of Public Policy \& Marketing, 26 (2), 289-292.

Moore, E.S. \& Rideout, V.J. (2007). The online marketing of food to children: is it just fun and games?, Journal of Public Policy and Marketing, 26 (2), Fall, 202-220.

Moschis, G. \& Churchill, G. (1978). Consumer socialization: a theoretical and empirical analysis, Journal of Marketing Research, 15, 599-609.

Moschis, G. \& Moore, R.L. (1979). Decision making among the young: a socialization perspective, Journal of Consumer Research, 6, September, 101-112.

Oestergaard P. \& Jantzen C. (2000). Shifting perspectives in consumer research: from buyer behaviour to consumption studies, in Beckmann S.C. \& Elliot R. (Eds.), Interpretive Consumer Research - Paradigms, Methodologies and Applications, Denmark: Copenhagen Business School Press..

Page, C. \& Ridgway, N. (2001). The impact of consumer environments on consumption patterns of children from disparate socioeconomic backgrounds, Journal of Consumer Marketing, Vol. 18, Issue 1, 21-41.

Perret-Clermont, A.-N. (1996). La construction de l'intelligence dans l'interaction sociale, 5 ième édition. Berne: Peter Lang.

Peile L. (2003). Insight through ethnography: researching children in a different way, Journal of Advertising and Marketing to Children, October-December, 63-67.

Piaget, J. (1948), La formation de l'intelligence,

Robertson, T. S. \& Feldman, S. (1976). Children as Consumers: the need for multi-theoretical perspectives, Advances in Consumer Research, Vol. 3, Issue 1, 508-512. 
Roedder-John, D. (1999). Consumer Socialization of Children - A Retrospective look at twenty-five years of research, Journal of Consumer Research, December, Vol. 26 (3), 183-213.

Roedder John, D. (2002). Consumer Socialization of Children - A Retrospective look at twenty-five years of research, in Hansen F., Rasmussen J., Martensen A. \& Tufte B. (Eds.) Children - Consumption, Advertising and Media, Copenhagen: Copenhagen Business School Press, 25-89.

Rogoff, B. (1998). Cognition as a collaborative process, In D. Kuhn \& R.S Siegler (Eds.) Cognition and language (vol.2, Handbook of Child Psychology ( $5^{\text {th }}$ Edition), W. Damon (Ed.),pp. 679-738. New york: Wiley.

Rogoff, B., Moore, L., Najafi B., Dexter, A., Correa-Chavez M., Solis, J. (2006).

Roland Lévy, C. (2002). National or supranational? Teenagers' feeling of belonging, International Journal of Advertising and Marketing to Children, Vol. 4 (1), October-December, 55-65.

Roland Lévy, C. (2003). Genesis and evolution of the representations of the Euro, Paper presented at the Euro-Workshop IAREP, Vienna, Austria, 3-5 July.

Selman, R.L. (1980). The Growth of Interpersonal Understanding, New York: Academic Press.

Siegel, D.L., Coffey, T.J. \& Livingstone, G. (2002). The great tween buying machine - Capturing your share of the multibillion dollar tween market, Chicago: Dearborn Trade Publishing

Sirota, R. (1998). Les copains d'abord. Les anniversaires de l'enfance, donner et recevoir, Ethnologie française, XXVIII, 4, 457-471.

Sirota, R. (1999). Les civilités de l'enfance contemporaine: l'anniversaire ou le déchiffrage d'une configuration, Dossier Sociologie de l'enfance 2, Education et Sociétés, N¹, 31-54

Strauss, A. (1952), The development and transformation of monetary meanings in the child, American Sociological Review, 17, June, 275-286

Tufte B. (2003). Children, media and consumption, International Journal of Advertising \& Marketing to Children, Vol. 5, Issue 1. World Advertising Research Center, 69-76.

Vygotsky, L. (1978). Mind in society, the development of higher psychological processes, Cambridge: Harvard University Press.

Vygotsky, L. (1934/1986). Thought and language. Cambridge MA: MIT Press.

Ward, S. (1974). Consumer Socialization, Journal of Consumer Research, 1, September, 1-14.

Wertsch, J.V. (1985). Vygotsky and the social formation of mind. Cambridge MA: Harvard University Press.

Woodhead, M. \& Faulkner, D. (2003). Subjects, Objects or Participants? Dilemmas of psychological research with children, in Christensen P. \& James A. (Eds.). Research with Children - Perspectives and Practices, London: Routledge Falmer. (First edition 2000), 9-35. 